\title{
Botanical Composition and Carrying Capacity in Various Agroecosystems on The
} Timor Island

\author{
Komposisi Botani dan Daya Dukung di Berbagai Agroekosistem di Pulau Timor
}

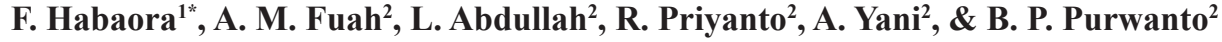 \\ ${ }^{1}$ Student of Post Graduate Programme Animal Production and Technology, Faculty of Animal Husbandry, \\ Bogor Agricultural University \\ ${ }^{2}$ Lecturer of Post Graduate Programme Animal Production and Technology, Faculty of Animal Husbandry, \\ Bogor Agricultural University \\ Jl. Agatis, Babakan-Dramaga, Bogor, West Java, 16680, Indonesia \\ *Corresponding author: habaorafhomas@gmail.com \\ (Received 12-02-2020; Revised 04-04-2020; Accepted 11-05-2020)
}

\begin{abstract}
This research aims to know the type of vegetation, nutrient components of feed and carrying capacity based on agroecosystems on Timor Island conducted from January-March 2018 (transition from the rainy season to the dry season). The research location was chosen purposively so that those it represented the pasture were in the District of Belu, Malaka, and TTU; agriculture in the District of Kupang and Kota Kupang; plantation in Kupang District; and forests in TTS District. Forage samples were taken using the $1 \times 1 \mathrm{~m} 2$ quadrant method. The quadrant is thrown at random. All vegetation in the quadrant is cut and analyzed in the laboratory. Descriptive data analysis. The result is that the main vegetation types of Bali cattle consumption in pasture agroecosystems is natural grass with a nutrient composition of ash (9.9\%), CP (5.7\%), CF (38.5\%), EE (2.2\%), NFE (36.4\%) and TDN (42.1\%). Agriculture agroecosystem is ricestraw with a nutrient composition of ash $(9.6 \%), \mathrm{CP}(5.8 \%), \mathrm{CF}(27.6 \%), \mathrm{EE}(2.1 \%), \mathrm{NFE}(48.8 \%$ ) and TDN (52.8\%). Plantation agroecosystems is lamtoro with a nutrient composition of ash (13.6\%), CP (12.0\%), CF (20.4\%), EE (3.3\%), NFE (42.8\%) and TDN (54.9\%). Forest agroecosystems is kabesak with a nutrient composition of ash (8.6\%), CP (11.5\%), CF (26.9\%), EE (1.2\%), NFE (44.2\%) and TDN $(53.1 \%)$. The carrying capacity of pasture, agriculture, plantation and forest in sequence are very high, namely $4.8 \mathrm{UT}$ and CCI 0.4 with an average body weight of $229.3 \mathrm{~kg} ; 5.6 \mathrm{UT}$ and CCI 0.6 with an average BB of $188 \mathrm{~kg} ; 6.8 \mathrm{UT}$ and CCI 0.7 with an average BB of $227.5 \mathrm{~kg}$; and $5.8 \mathrm{UT}$ and CCI 0.7 with an average BB of $194.9 \mathrm{~kg}$. The entire agroecosystem area on Timor Island is classified as a very critical area.
\end{abstract}

Keywords: vegetation type, nutrient composition, carrying capacity, agroecosystem

\section{ABSTRAK}

Penelitian ini bertujuan untuk mengetahui jenis vegetasi, komponen nutrien pakan dan daya dukung berbasis agroekosistem di Pulau Timor yang dilakukan mulai bulan Januari-Maret 2018 (transisi musim hujan ke musim kemarau). Lokasi penelitian dipilih secara purposive sehingga yang mewakili pasture di Kab.Belu, Malaka, dan TTU; pertanian di Kab.Kupang dan Kota Kupang; perkebunan di Kab.Kupang; dan hutan di Kab.TTS. Pengambilan sampel hijauan dilakukan dengan metode kuadran ukuran 1x1m2. Kuadran dilempar secara acak. Semua vegetasi dalam kuadran dipotong dan dianalisis di laboratorium. Analisis data secara deskriptif. Hasilnya adalah jenis vegetasi utama konsumsi sapi Bali di agroekosistem pasture adalah rumput alam dengan komposisi nutrien abu $(9,9 \%)$, PK (5,7\%), SK $(38,5 \%)$, LK (2,2\%), Beta-N (36,4\%) dan TDN (42,1\%). Kemudian di agroekosistem pertanian adalah jerami padi dengan komposisi nutrien abu $(9,6 \%)$, PK (5,8\%), SK $(27,6 \%)$, LK $(2,1 \%)$, Beta-N $(48,8 \%)$ dan TDN (52,8\%). Selanjutnya di agroekosistem perkebunan rakyat adalah lamtoro dengan komposisi nutrien abu (13,6\%), PK (12\%), SK (20,4\%), LK (3,3\%), Beta-N (42,8\%) dan TDN (54,9\%). Sedangkan di agroekosistem hutan rakyat adalah kabesak dengan komposisi nutrien abu (8,6\%), PK (11,5\%), SK (26,9\%), LK (1,2\%), Beta-N (44,2\%) dan TDN (53,1\%). Kapasitas tampung pasture, pertanian, perkebunan, dan hutan secara berurutan sangat tinggi, yaitu 4,8 UT dan IDD 0,4 dengan berat badan rata-rata 229,3 kg; 5,6 UT/ha/tahun dan IDD 0,6 dengan BB rata-rata $188 \mathrm{~kg} ; 6,8 \mathrm{UT} / \mathrm{ha} /$ tahun dan IDD 0,7 dengan BB rata-rata 227,5 kg; dan 5,8 UT dan IDD 0,7 dengan BB rata-rata 194,9 kg. Dengan demikian seluruh wilayah agroekosistem di Pulau Timor tergolong wilayah sangat kritis.

Kata kunci: komposisi botani, komposisi nutrien, kapasitas tampung, agroekosistem. 


\section{INTRODUCTION}

Forage is an important factor that can affect productivity of livestock, so forage must be considered for availability (Herdiawan et al. 2014). Human intervention is an important factor in the availability of forage. A good forage can be seen from the quality and nutrient content. In addition, good forage must be fulfilled quality and quantity continuously throughout the year.

One of the common obstacles faced by farmers in Indonesia is the availability of forage which is strongly influenced by the season and educed land area as a source of feed procuremen. During the rainy season, forages are abundant, whereas in the dry season it is very difficult to obtain (Ali et al. 2014). the shortage of feed for livestock is a serious challenge in developing livestock in Indonesia. Indications of a lack of feed and nutritional supply are characterized by low levels of livestock production produced.

Nusa Tenggara Timur (NTT), with the popular as a province of livestock, especially cattle, relies mainly on forage which is the cheapest source of feed (native grass). The main source of forage can be assessed based on the potential of agroecosystems in each area. The Bali cattle production area in NTT namely Timor Island with a population distribution of $65.97 \%$ of the total cattle population in NTT totaling 899,577 cattle (Disnak NTT 2016). But the productivity of Bali cattle on Timor Island is still relatively low due to several reasons, including (1) high calf mortality (35-40\% per year); (2) high heifer mortality $(>20 \%$ per year); (3) slaughter of productive cows in RPH reaches $>$ $60 \%$ of the total slaughter of cattle; (4) feed limitations due to season; (5) traditional livestock raising systems with low production inputs; (6) the occurrence of endemic brucellosis and anthrax with a high prevalence (14.6-40.8\%) in the last 10 years; (7) supervision of livestock exports is still weak so that the realization of exports is higher than the stipulated quota; (8) there was a decrease in export weight of Bali cattle from $450 \mathrm{~kg} /$ cattle in $1970-1980$ to $275 \mathrm{~kg}$ per cattle in 2015 (Lole et al. 2013; Mahbubi 2015; Kleden et al. 2015; Disnak NTT 2016; Priyanto 2016) .

Timor Island is a dry land type area so that the limited feed is a delay (disruption) in cattle productivity. Besides that, maintenance management of Bali cattle still traditional causes input from livestock is still low. The main problem that often occurs is the lack of understanding of farmers about feed management. The utilization of feed according to agroecosystem conditions has not been done well so that feed is always limited even though it has enormous potential. Giving Feed based on rice straw waste $10-50 \%$ in the ration can increase the average body weight gain of 0.9 $\mathrm{kg} /$ cattle/day and increases the average feed consumption of $4.2 \mathrm{~kg} /$ cattle/day (Corriher et al. 2010; Jabari et al. 2011; Indrianingsih et al. 2012). Then Laconi (2014) reported that the combination of plant rations from plantations given to feeder steer was able to increase the body-weight of cattle by an average of $1.4 \mathrm{~kg} /$ cattle/day. Whereas feed management in agroecosystems of pasture and forest can increase maximum livestock production.
The utilization of feed according to agroecosystem conditions has not been well organized. This is because the use of agroecosystems as the carrying capacity of animal feed is strongly influenced by the socio-culture and characteristics of farmers (Kleden et al. 2015; Riwukore and Habaora 2018; Riwukore and Habaora 2019a,b). Utilization land of agriculture and plantation as a source of feed provider for livestock only reaches $<45.57 \%$ of the potential carrying capacity index $>2$ (over-feed). Whereas the use of forest agroecosystems as a feed provider for cattle only reached 24.20\% (Yuhendra 2010; Indraningsih et al. 2012; Abdullah 2016; Sahab et al. 2015; Gunawan 2015; Saputra et al. 2016; Riwukore and Habaora 2019a,b). In general, the use of agroecosystem based feeds only reached $<$ $34.9 \%$. Utilization of land agroecosystems has the potential to develop beef cattle based on agroecosystems which reach $60.7-87.0 \%$ of dry agricultural land, plantations, rice fields, savannahs, forests, and shrubs need to be innovated by Bali cattle farmers. An agroecosystem is a reciprocal relationship between agroecosystem-forming components (abiotic or biotic) to get the maximum benefit by considering aspects of productivity, tapability, sustainability, and equity. Varied agroecosystems determine the productivity of Bali cattle according to the potential of each agroecosystem. If it can be managed properly, it has the potential as a strength to support the sustainable increase in Bali cattle production. Increasing Bali cattle production will be able to increase income and also guarantee the export capability of cattle.

In a practical setting, empirical experience shows that the dynamics of processes in the field of livestock vary according to the culture and management of farms that apply to an agroecosystem. The agroecosystem based on land use type consists of pasture, agriculture, plantation, and forest. Each of these agroecosystems affects the production inputs of Bali cattle farms. So far, there is no information and data that can provide a clear picture of the productivity of Bali cattle based on the carrying capacity of agroecosystems that vary from animal feed management outputs. Therefore research was conducted using a varied agroecosystem approach to determine the type of vegetation, components of feed nutrients and carrying capacity of sustainable feed on Timor Island. The purpose of this research was to obtain data and information on vegetation types, components of feed nutrients and feed carrying capacity in four Timor Island agroecosystems, namely pasture, agriculture, plantation, and forest.

\section{MATERIALS AND METHODS}

\section{Location and Method of Taking Samples}

This research was conducted in Timor Island, Nusa Tenggara Timur Province, Indonesia, during transition of rainy season to dry season (January-March). The research locations were selected purposively based on physical criteria (land area), biology/agroecosystem, and social so that sampling locations represented pastures are located in District of Belu, Malaka and Timor Tengah Utara (TTU), which represent agricultural land in Kupang District and Kota Kupang, which represent plantation land in Kupang 
District, and which represent forests in Timor Tengah Selatan District (TTS). Forage sampling was carried out by a destructive sampling method (Mannetje and Haydock 1963; Damry 2009) using a pair of quadrants with an individual size of $1 \times 1 \mathrm{~m}$. The pairs of quadrants are placed randomly at the sampling location with the interval between one sampling point and the next point about $10 \mathrm{~m}$, following two parallel transects about $20 \mathrm{~m}$ apart. All vegetation in each quadrant is cut using sickles and scissors, and the sample is placed in a paper envelope for then analysis in the laboratory.

\section{Laboratory Analysis}

Laboratory analysis was carried out at the Laboratory of Feed Science and Technology, Division of Technology and Feed Industry, Department of Feed Nutrition and Technology, Faculty of Animal Husbandry, Bogor Agricultural University. Proximate analysis of forage samples that have been collected are carried out to determine the content of dry matter (DM) and main nutrients such as ash, crude protein (CP), crude fiber (CF), extract ether (EE), and nitrogen free extract (NFE) in the sample.

\section{Data Analysis}

Based on the analysis of forage dry matter content, it can be calculated several parameters of the availability of feed-in each agroecosystem related to the available forage production, needs of land area for livestock per unit of time, the land carrying capacity. Several assumptions are used in the calculation. Available forage production is the total amount of forage that can be produced by agroecosystems (expressed in dry matter) minus the production of weed components, multiplied by the proper use factor (PUF) used is 70\% (Habaora 2015; Habaora and Riwukore 2018). The need for land area per month for cattle (ha / UT) is the amount of livestock forage needs for a month $(\mathrm{kg} / \mathrm{UT})$ divided by the available forage production $(\mathrm{kg} / \mathrm{ha})$ of each agroecosystem in question. Livestock land area needs per year (ha/UT) are calculated using the formula Voisin (1995). The carrying capacity of each agroecosystem is calculated according to Reksohadiprodjo (1985), assuming that one livestock unit (UT) in each agroecosystem is equivalent to the average data from the estimated weight of cattle in this research, namely the average weight of cattle in pasture agroecosystems $(229.3 \mathrm{~kg})$, agriculture (188.0), plantations $(227.5 \mathrm{~kg})$, and forests $(194.9 \mathrm{~kg})$, with animal feed requirements per day (in the form of dry matter) set at 3\% of body weight, and that the period stay (grazing) is 70 days (Susetyo 1980). Research data were analyzed and delivered descriptively.

\section{RESULTS AND DISCUSSION}

\section{Botanical Composition}

Information about vegetation types based on agroecosystems on Timor Island can be seen in Table 1. Information in Table 1 shows the types of grass found in the pasture agroecosystem research site are 5 species, consisting of 3 graminae types and 2 legume species. Graminae species are dominated by rumput kinangan (Paspalum scrobiculatum), rumput belulang (Eleusine indica), rumput limpo (Hemarthria altisima), rumput mutiara (Oldenlandia $s p$ ) and sisik betok (Desmodium triflorum). Paspalum $s p$ species are generally found growing in grassy areas and wood openings in low, moist, sandy soils and along brackish marshes. Eleusine indica is a type of drought-resistant plant classified as weed on cultivated plants and golf courses, can thrive on solid soil and in full sun. This type of grass grows wild, usually on a field or roadside, has few fine hairs, strong roots. Oldenlandia is a plant that lives in open areas up to 1,500 meters above sea level including alongside roads, gardens, arable land, grasslands, open forests and river banks (Putra et al. 2018). Bali cattle in the pasture agroecosystem are also given additional feed such as kabesak, rice straw, corn straw and Leucaena lecocephala. While the use of concentrate more commonly is putak and rice bran. Giving superior grass to Bali cattle in the pasture agroecosystem is generally not done by farmers.

The main type of vegetation consumed by Bali cattle in agricultural agroecosystems is rice straw. Farmers also provide additional feed to livestock such as kinangan grass, kume grass, banana stem, corn straw, and peanut straw. The type of superior grass that tends to be given to cattle is king grass. Types of concentrate feed given as reinforcement are rice bran and putak. Furthermore, Bali cattle farmers in agroecosystem of plantations often provide of main feed to livestock is lamtoro. In addition, additional types of feed are also provided such as kume grass, kabesak leaves, peanut straw, and corn straw. The superior type of grass that is often given to Bali cattle is king grass. The type of concentrate feed that is often given is rice bran, tofu dregs, and putak.

While the type of main feed consumed by Bali cattle in the forest agroecosystem is kabesak. Kabesak is a plant species that is known to have important benefits for the local population of Timor Island. The people of Timor Island use kabesak leaves as animal feed in the dry season and the wood is used as a building material and furniture (Fuah et al. 2013; Hendrik et al. 2019). In addition, farmers also provide lamtoro leaves, banana stem, kersen leaves, kesambi, beringin leaves, and asam leaves. The type of supplement feed that is often given is putak.

\section{Nutrient Composition of Edible Forages}

Feedings livestock needs to consider livestock nutritional needs in accordance with the conditions of body weight and maintenance objectives. Information about the quality of feed nutrients based on agroecosystems is presented in Table 2. The results of this research indicate that the crude protein content of forages growing in plantation agroecosystems $(12.0 \%)$ and forests $(11.5 \%)$ are higher than forages plant from pasture agroecosystems $(5.7 \%)$ and agricultural agroecosystems (5.84\%). The difference in the crude protein content of the forage in each agroecosystem is due to differences in plant species. The composition of forage species in agroecosystems of plantation and forest is dominated by legumes while in agroecosystems of pasture and agriculture are dominated by gramineae. Plant species classified as legumes have higher crude protein content compared to gramineae plant varieties. 
Habaora et al.

Jurnal Ilmu Produksi dan Teknologi Hasil Peternakan 8 (2): 72-79

Table 1. Botanical composition as a forage source based on agroecosystems on Timor Island

\begin{tabular}{|c|c|c|c|c|}
\hline \multirow[t]{2}{*}{ No. } & \multirow[t]{2}{*}{ Agroecosystem } & \multicolumn{3}{|c|}{ Type of Vegetation } \\
\hline & & Main & Supplementary & Concentrate \\
\hline \multirow[t]{5}{*}{1} & Pasture & $\begin{array}{l}\text { Kinangan grass } \\
\text { (Paspalum scrobiculatum) }\end{array}$ & Kabesak (Acacia leucophloea) & Bran \\
\hline & & Belulang grass (Eleusine indica) & Rice straw (Oryza sativa L.) & Putak (Corypha gebanga) \\
\hline & & Limpo grass (Hemarthria altisima) & Corn straw (Zea mays L.) & \\
\hline & & Mutiara grass (Oldenlandia sp.) & Lamtoro (Leucaena leucocephala) & \\
\hline & & $\begin{array}{l}\text { Sisik betok grass (Desmodium tri- } \\
\text { florum) }\end{array}$ & Beringin (Ficus benjamina) & \\
\hline \multirow[t]{6}{*}{2} & Agriculture & Rice straw (Oryza sativa L.) & $\begin{array}{l}\text { Kinangan grass } \\
\text { (Paspalum scrobiculatum) }\end{array}$ & Bran \\
\hline & & & $\begin{array}{l}\text { Kume grass } \\
\text { (Shorgum plumosum var. Timorense) }\end{array}$ & Tofu dregs \\
\hline & & & Banana stem (Musa acuminata) & Putak (Corypha gebanga) \\
\hline & & & Corn straw (Zea mays L.) & \\
\hline & & & Peanut straw (Arachis hypogaea L.) & \\
\hline & & & King grass (Pennisetum purpuphoides) & \\
\hline \multirow[t]{5}{*}{3} & Plantations & Lamtoro (Leucaena leucocephala) & $\begin{array}{l}\text { Kume grass } \\
\text { (Shorgum plumosum var. Timorense) }\end{array}$ & Putak (Corypha gebanga) \\
\hline & & & Kabesak (Acacia leucophloea) & Tofu dregs \\
\hline & & & Peanut straw (Arachis hypogaea L.) & \\
\hline & & & Corn straw (Zea mays L.) & \\
\hline & & & King grass (Pennisetum purpuphoides) & \\
\hline \multirow[t]{6}{*}{4} & Forest & Kabesak (Acacia leucophloea) & Lamtoro (Leucaena leucocephala) & Putak (Corypha gebanga) \\
\hline & & & Banana stem (Musa acuminata) & \\
\hline & & & Kersen (Muntingia calabura) & \\
\hline & & & Beringin (Ficus benjamina) & \\
\hline & & & Asam (Tamarindus indica) & \\
\hline & & & Kusambi (Schleichera oleosa) & \\
\hline
\end{tabular}

The crude protein content of Leucaena lecocephala in the agroecosystem of plantations is lower than the results of proximate analysis from Lani et al. (2015) at the same research location, which is an average of $23.6 \%$. Then the crude protein content of kabesak in the forest agroecosystem is lower than the proximate analysis results from Lawa et al. (2017) at the same research location on average ie $15 \%$. While the crude protein content of forage types of rice straw in agricultural agroecosystems and native grass types of Paspalum sp. in the pasture agroecosystem shows conditions that are not much different from crude protein content generally on Timor Island and NTT, which is 5-8\% (Kleden 2002; Damry 2009; Kleden et al. 2015; Tabun et al. 2016).

The circumstances of this research indicate that the type of feed consumed by livestock in each agroecosystem tends to be a source of energy and a source of fiber. Forage food which has a crude fiber content of more than $18 \%$ is a source of fiber and feed ingredients that have protein content $<20 \%$ are a source of energy. The difference in the quality of forage nutrition is very likely influenced by climatic conditions when forage sampling, undergrazing conditions, as well as other factors including the composition of grass with legumes, forage growth stages, soil conditions, fertilization, and soil availability.

Kleden et al. (2015) reported that the dry season in NTT (Timor Island) accelerated forage aging where the crude fiber content was higher with a protein content which low was $6,0 \%$ in the rainy season would decrease to 3,0 $5,0 \%$ in the dry season and increase the content cell walls from $65 \%$ to $85 \%$ in the dry season. Damry (2009) explains that undergrazing condition is causing existing vegetation to experience aging with high crude fiber content. In addition, forage sampling at the research site between the dry and rainy seasons has an influence on the results of feed nutrition analysis. Likewise, other factors that influence the quality of feed include legumes that contain higher nitrogen compared to grass and the low proportion of legumes present in vegetation that grow to be one of the causes of the low quality of existing forage nutrients (Yani et al. 2011; Hawolambani et al. 2015; Priyanto et al. 2015; Lawa et al. 2017). Lani et al. (2015) states that this difference is caused by differences in variety, soil fertility, harvest age, ie young leaves has a higher protein content compared to old leaves, climate, as well as the composition of the leaves and petiole mixture. 
Habaora et al.

Jurnal Ilmu Produksi dan Teknologi Hasil Peternakan 8 (2): $72-79$

Table 2. Composition of forage nutrition based on agroecosystem in Timor Island

\begin{tabular}{rlcccccc}
\hline \multirow{2}{*}{ No. } & \multirow{2}{*}{ Agroecosystem } & \multicolumn{5}{c}{ Feed Nutrition (\% Dry Matter) } \\
\cline { 3 - 7 } & & Ash & CP & CF & EE & NFE & TDN \\
\hline 1 & Pasture & 9.9 & 5.7 & 38.5 & 2.2 & 36.4 & 42.1 \\
2 & Agriculture & 9.6 & 5.8 & 27.6 & 2.1 & 48.8 & 52.8 \\
3 & Plantations & 13.6 & 12.0 & 20.4 & 3.3 & 42.8 & 54.9 \\
4 & Forests & 8.6 & 11.5 & 26.9 & 1.2 & 44.2 & 53.1 \\
\hline Inf: & CP = Crude Protein, CF = Crude Fiber, EE = Extract Ether, NFE = Nitrogen Free Extract, TDN = Total Digestible Nitrogen (Hasil
\end{tabular}

Protein is a nutrient that is very important for livestock life and growth. The crude protein content that is too low will not be able to meet the body's protein needs, both for the needs of rumen microbes and the amino acid needs of cattle. The growth of microbes that are not optimum in the rumen causes the rumen microbes are also unable to perform their functions optimally in the process of breaking down the components of forage crude fiber and providing amino acids for cattle. Rumen microbes are the main source of amino acids that are available for digestion and absorption in the small intestine for later use in fulfilling livestock maintenance and production needs.

Then according to the information in Table 2 about the content of crude fiber of livestock forage in each agroecosystem shows that the highest forage crude fiber content is forage in a pasture $(38.5 \%)$, agriculture $(27.6 \%)$, forest $(26.9 \%) \%$ ), and plantations $(20.4 \%)$. The results of this research indicate that the forage crude fiber content in each agroecosystem is very high so that it can affect the digestibility of Bali cattle. Xu et al. (2014) and Suryani et al. (2015) states that feed digestibility is closely related to its chemical composition and crude fiber has the greatest influence on digestibility. Crude fiber in ruminant livestock rations is very important to maintain healthy rumen conditions and support microbial protein synthesis by maintaining stable rumen conditions. Mayulu and Suhardi (2016) stated that the limitations possessed forage with crude fiber content that is above the tolerance limit of $18 \%$. The high crude fiber content indicates that the structural fraction of carbohydrate in the feed is very likely to be utilized by Bali cattle, but in the process of metabolism, it requires the availability of other components in the form of energy.

Crude fiber contains ingredients needed from plant cell walls, including cellulose, pentose, lignin and cutine. Lignin and cutine are not digested, whereas cellulose and pentose with the help of rumen microorganisms can be digested and are a fairly high energy source. Crude fiber is a class of carbohydrates that functions to fill and maintain the digestive system to work properly, and encourage digestive glands to excrete digestive enzymes. The presence of sufficient crude fiber content in Bali cattle feed causes higher consumption of dry matter intake which is used to arrange body cells. Ruminants will have indigestion if the crude fiber in the rumen is too low, at least $13-15 \%$ of the dry matter in the ration consists of crude fiber (Ahmad et al. 2004; Pasambe et al. 2006; Suryani et al. 2015; Wiryawan et al. 2017).
Furthermore, the energy content produced through the calculation of total digestible nutrients (TDN) provides information on the energy potential of the feed that can be used as a source of constituent ingredients for Bali cattle feed. Based on the results of the TDN calculation through the Owens et al. (2010), it is known that TDN content of feed types in each agroecosystem starts from highest to low, namely forage in plantation agroecosystems (54.9\%), forest agroecosystems (53.1\%), agriculture agroecosystems $(52.8 \%)$, and pasture agroecosystem $(42.1 \%)$. The results of this calculation indicate that the TDN value is too low according to the instructions of Kearl (1983) and NRC (1984) that the ideal consumption of feed ingredients containing energy from TDN ranges from $60-70 \%$ (Lani et al. 2014). The results of this study indicate that the use of high biological value forage as a source of food has not been able to support the needs of Bali cattle for nutrients. This situation is caused by forage of high biological value and limited availability, especially in the dry season. The growth of Bali cattle is very dependent on the quality of the nutrients contained in each feed ingredient that is eaten.

Some researchers report that the treatment of energy rations at the level of TDN $57.9-69.7 \%$ with a relatively similar protein composition between $12.4-12.9 \%$ is capable of producing weight gain between $0.7-1.6 \mathrm{~kg} / \mathrm{cattle} /$ day in Sumba Ongole cattle kept for 6 months and average body weight of $254.7 \mathrm{~kg}$ (Ngadiyono et al. 2008; Nusi et al. 2011; Lestari et al. 2011; Aditia et al. 2013; Priyanto et al. 2015). The higher level of TDN results in a high cow weight gain. Increasing livestock productivity requires the availability of animal feed continuously both quality and quantity so that the potential of the area in the supply of forage and the need to fulfill animal feed needs to be known so that optimal utilization of forage resources can be made by taking into consideration the continuity of forage supply throughout the year (Infitria and Khalil 2014; Shiddieqy et al. 2017).

\section{Carrying Capacity}

Feed resources are basically closely related to carrying capacity. Carrying capacity is interpreted as the ability of agroecosystems to produce feed ingredients to ensure the availability and fulfill the needs of a number of ruminant populations in both fresh and dry form and its use is assumed to fulfill the needs of Bali cattle. The results of the analysis of the determination of dry matter showed that the forage contained 46.3 (pasture), 47.0 (agriculture), 46.0 (plantation), and 46.2 (forest) grams per 100 grams 
Table 3. Carrying capacity based on agroecosystem in Timor Island

\begin{tabular}{lccccc}
\hline Parameters & Units & \multicolumn{4}{c}{ Agroecosystem } \\
\cline { 3 - 6 } & & Pasture & Agriculture & Plantations & Forests \\
\hline Production of forage dry matter & $\mathrm{g} / \mathrm{m}^{2}$ & 46.3 & 47 & 46 & 46.2 \\
Production of forage dry matter & $\mathrm{kg} / \mathrm{ha}$ & 4633 & 4697 & 4605 & 4619 \\
Production dry matter & $\mathrm{kg} / \mathrm{ha}$ & 4633 & 4697 & 4605 & 4619 \\
Production of forage dry matter is available & $\mathrm{kg} / \mathrm{ha}$ & 3243 & 3288 & 3223 & 3233 \\
Weight gain 1 units cattle (UT) & $\mathrm{kg}$ & 229.3 & 188 & 227.5 & 194.9 \\
Needs of feed dry matter (3\% WG) & $\mathrm{kg} /$ day & 6.9 & 5.6 & 6.8 & 5.8 \\
Needs of feed dry matter (30 day) & $\mathrm{kg} / \mathrm{month}$ & 206.37 & 169.2 & 204.75 & 175.41 \\
Needs of land area for cattle per month & $\mathrm{ha} / \mathrm{UT} / \mathrm{month}$ & 0.1 & 0.1 & 0.1 & 0.1 \\
Needs of land area for cattle per year & $\mathrm{ha} / \mathrm{UT} / \mathrm{year}$ & 0.2 & 0.2 & 0.2 & 0.2 \\
Carrying capacity & $\mathrm{ha} / \mathrm{UT} / \mathrm{year}$ & 4.8 & 5.9 & 4.8 & 5.6 \\
Land area & ha & 105 & 117 & 147 & 122 \\
Total carrying capacity & $\mathrm{UT} / \mathrm{ha} /$ year & 500 & 689 & 701 & 681 \\
Riil population & $\mathrm{UT}$ & 1187 & 1142 & 1055 & 988 \\
Carrying capacity index & & 0.4 & 0.6 & 0.7 & 0.7 \\
\hline
\end{tabular}

of fresh matter with a dry matter production rate of $463 \mathrm{~g} /$ $\mathrm{m}^{2}$ (pasture), $470 \mathrm{~g} / \mathrm{m}^{2}$ (agriculture), $460 \mathrm{~g} / \mathrm{m} 2$ (plantation), and $462 \mathrm{~g} / \mathrm{m}^{2}$ (forest). Based on the content and production of the dry matter and the assumptions used, a number of parameters were calculated and the results are shown in Table 3.

The calculation results show that the carrying capacity of pasture, agriculture, plantation, and forest is very high, which is 4.8 units of livestock in the pasture agroecosystem (a cattle with an average body weight of $229.3 \mathrm{~kg}$ ); 5.6 livestock units in an agricultural agroecosystem (a cattle weighing an average of $188.0 \mathrm{~kg}$ ); 6.8 units of livestock in the agroecosystem of plantations (a cattle with an average weight of $227.5 \mathrm{~kg}$ ); and 5.8 livestock units in a forest agroecosystem (a cattle weighing an average of 194.9 $\mathrm{kg}$ ). This carrying capacity value is higher than the ideal carrying capacity according to Reksohadiprojo (1985), which is $2.5 \mathrm{UT} / \mathrm{ha} /$ year. This situation shows that land in agroecosystems of pasture, agriculture, plantation, and forest generally has been overgrazed if there is an increase in livestock body weight to $500 \mathrm{~kg}$ per cattle.

The average land carrying capacity index in agroecosystems of pasture, agriculture, plantation, and forest are $<1$, which means it is classified as a very critical area. Juarini et al. (2011) states that areas with a land carrying capacity index $<1$ are areas of feed shortage with a long dry season which causes thin cattle, young cattle to be sold to other areas as breeding/fattening, and grazing land degradation. In addition, this region is classification as very dense cattle.

\section{CONCLUSION}

The results showed that the main types of biological vegetation in Bali cattle consumption in pasture agroecosystems were grasses with an average crude protein content of $5.7 \%$, namely: kinangan grass, belulang, limpo, mutiara, and sisik betok. Rice straw with crude protein content of an average of $5.8 \%$ is the main type of feed for Bali cattle in agroecosystems. Lamtoro plant species with $12 \%$ crude protein composition are the main feed types in plantation agroecosystems, while kabesak plants with jkasar protein composition $11.5 \%$ are the main feed types consumed by Bali cattle in forest agro-systems. The carrying capacity of pasture, agriculture, plantation and forest in sequence are very high, namely 4.8 UT and CCI 0.4 with an average body weight of $229.3 \mathrm{~kg} ; 5.6 \mathrm{UT}$ and CCI 0.6 with an average BB of $188 \mathrm{~kg} ; 6.8 \mathrm{UT}$ and CCI 0.7 with an average BB of 227.5 $\mathrm{kg}$; and 5.8 UT and CCI 0.7 with an average BB of 194.9 $\mathrm{kg}$. Thus the entire agroecosystem area on Timor Island is classified as a very critical area.

\section{CONFLICT OF INTEREST}

We certify that there is no conflict of interest with any financial, personal, or other relationships with other people or organization related to the material discussed in the manuscript.

\section{REFERENCES}

Ali, A., L. Abdullah, P. D. M. H. Karti, M. A. Chozin, \& D. A. Astuti. 2014. Evaluation, productivity and competition of Brachiaria decumbens, Centrocema pubescens and Clitoria ternatea as Sole and Mixed Cropping Pattern in Peatland. IJAVS. 19:81-90.

Abdullah, A. 2016. The technology adoption process of rice straw as feed for beef cattle on small farmers in Bulukumba Regency, Sounth Sulawesi. J. Soc. Scie. Hum. 18(1):1-9.

Aditia, E. L., R. Priyanto, M. Baihaqi, B. W. Putra, \& M. Ismail. 2013. Performa produksi sapi Bali dan Peranakan Ongole yang digemukkan dengan pakan 
berbasis sorgum. Jurnal Ilmu Produksi dan Teknologi Hasil Peternakan. 1:155-159.

Ahmad, S. N., D. D. Siswansyah, \& D. K. S. Swastika. 2004. Kajian sistem usaha ternak sapi potong di Kalimantan Tengah. Jurnal Pengkajian dan Pengembangan Teknologi Pertanian. 7(2):155-170.

Corriher, V. A., G. M. Hill, J. K. Bernard, \& Jr. B. G. Mullinix. 2010. Performance of finishing steers on corn silage or forage sorghum silage with corn oil supplementation. The Professional Animal Scientist. 26:387-392.

[Disnak NTT] Dinas Peternakan Provinsi Nusa Tenggara Timur. 2016. Laporan Tahunan. Kupang. Pemrov NTT.

Damry. 2009. Production and nutrients composition of forages produced from a natural grassland in Lore Utara Subdistrict, Poso District. Agroland Journal. 16(4):296-300.

Fuah, A. M., P. D. M. H. Karti, R. Priyanto, B. Masyud, \& Salundik. 2013. Paradise in Timor Island-TTS Regency: Prospective land for agri-farming, exotic place for adventure. Jakarta (ID): Gramedia Press.

Gunawan, I. 2015. Analisis Strategi Pengembangan Usaha Komoditas Unggulan Pertanian di Kabupaten Rokan Hulu. Jurnal Sungkai. 3(2):1-17.

Habaora, F. 2015. Produksi Ternak Gembala. Yogyakarta (ID): Penerbit Deepublish.

Hawolambani, Y. U., H. P. Nastiti, \& Y. H. Manggol. 2015. Production animal feed forage and composition botanical field natural grazing on rainy season in Amarasi West District Kupang Regency. Jurnal Nukleus Peternakan. 2(1):59-65.

Hendrik, A. C., C. Kusmana, \& Muhdin. 2019. Stand and site characteristics of kabesak (Acacia leucophloea) in Timor Island, East Nusa Tenggara, Indonesia. Jurnal Penelitian Kehutanan Wallacea. 8(2):147-157.

Herdiawan, I., L. Abdullah, \& D. Sopandi. 2014. Nutrional status of Indigofera zollingeriana forage at different level draught stress and cutting interval. IJAVS. 19(2):19-103.

Indraningsih, R., Widiastuti, \& Y. Sani. 2012. Limbah Pertanian dan Perkebunan sebagai Pakan Ternak: Kendala dan Prospeknya. Lokakarya Nasional IPTEK dalam Pengendalian Penyakit, Strategi pada Ternak Ruminansia Bogor. 99-115.

Infitria \& Khalil. 2014. Studi produksi dan kualitas hijauan di lahan pada rumput UPT Peternakan Universitas Andalas Padang. Buletin Makanan Ternak. 10(1):2533.

Jabbari, H., S. N. Tabatabaei, E. Kordnejad, M. Modarresi, \& S. A. Tabeidian. 2011. Effect of Dietary Corn Silage Replacement With Sorghum Silage on Performance and Feed Cost of Growing Steers. Online Journal of Animal and Feed Research. 1(1):14-21.

Juarini, E., Sumanto, B. Wibowo, \& Suratman. 2011. Carrying capacity of forage and crop waste for development of buffalo and cattle to support meat self sufficiency in 2014 in Lebak District. Proceeding of National Seminar on Livestock and Veterinary
Technology. Bogor (Indonesia): Indonesia Center for Animal Research and Development. p. 292-299.

Kleden, M. M. 2002. Natural grassland capacity in support of beef cattle development at the Subdistrict of Kupang Timur, Kupang District. Journal of Dryland Agriculture Information. 15:77-85.

Kleden, M. M., M. R. D. Ratu, \& M. D. S. Randu. 2015. Carrying capacity of forage in coffee farm and native pasture area at District of Flores Timur-East Nusa Tenggara. Zootrek Journal. 35(2):340-350.

Laconi, E. B. 2014. Harmonisasi Kebijakan Integrasi SapiPerkebunan untuk Mencukupi Kebutuhan Daging [Orasi Ilmiah Guru Besar]. Bogor (ID): Institut Pertanian Bogor, 6 Desember 2014.

Lani, M. L., L. Abdullah, \& R. Priyanto. 2015. Utilization of Leucaena leucocephala in traditional fattening program of Bali cattle in Amarasi. J. Med. Pet. 38(1):64-69.

Lawa, E. D. W., Marjuki, Hartutik, \& S. Chuzaemi. 2017. Effect of white kabesak (Acacia leucophloea Roxb) leaves level in the diet on feed intake and body weight gain of Kacang goat. J. Indonesian. Trop. Anim. Agric. 42(4):255-262.

Lestari, C. M. S., R. Adiwinarti, M. Arifin, \& A. Purnomoadi. 2011. The performance of Java and Ongole crossbreed bull under intensive feeding management. J. Indonesian. Trop. Anim. Agric. 36(2):109-113.

Lole, U. R., S. Hartoyo, Kuntjoro, \& I. W. Rusastra. 2013. Analysis of regional distribution capacity and priorities for improving beef cattle population in East Nusa Tenggara Province. J. Med. Pet. 36(1):70-78.

Mahbubi, A. 2015. Development program of Madura as an Island of Cattle: Sustainable supply chain management perspective. J. Agriekonomika. 3(2):94-105.

Mannetje, L. T., \& K. P. Haydock. 1963. The dry-weightrank method for the botanical analysis of pasture. J. B. Grassld. Soc. 18:268-275.

Mayulu, H., \& Suhardi. 2016. Potency and carrying capacity of rice straw for beef cattle feeding in East Kalimantan. Jurnal Ilmu dan Teknologi Peternakan (JITP). 4(3):119-129.

Ngadiyono, N., G. Murdjito, A. Agus, \& U. Supriyana. 2008. Kinerja produksi sapi Peranakan Ongole jantan dengan pemberian dua jenis konsentrat yang berbeda. J. Indonesian. Trop. Anim. Agric. 33(4):282-289.

Nusi, M., R. Utomo, \& Soeparno. 2011. Pengaruh penggunaan tongkol jagung dalam complete feed dan suplementasi undergraded protein terhadap pertambahan bobot badan dan kualitas daging pada sapi Peranakan Ongole. Buletin Peternakan. 35(3):173181.

Owens, F. N., D. A. Sapienza, \& A. T. Hassen. 2010. Effect of nutrient composition of feeds on digestibility of organic matter by cattle review. J. Anim. Sci. 88:151169.

Pasambe, D., M. Sariubang, \& Nurhayu. 2006. Influence of feeding improvement on beef production of fattening Bali cattle. Proceeding of National Seminar 
on Livestock and Veterinary Technology. Bogor (Indonesia): Indonesia Center for Animal Research and Development. p. 67-75.

Priyanto, D. 2016. Strategies to return East Nusa Tenggara as a source of beef cattle. Jurnal Litbang Pertanian. 35(4):167-178.

Priyanto, R., A. M. Fuah, E. L. Aditia, M. Balhaqi, \& M. Ismail. 2015. Improving productivity and meat quality of local beef cattle through fattening on cereals based feed with different energy levels. Jurnal Ilmu Pertanian Indonesia (JIPI). 20(2):108-114.

Putra, R. K., H. P. Nastiti, \& Y. H. Manggol. 2018. Botanical composition and forages production of pastures in Letneo Village of West Insana District, TTU Regency. Jurnal Nukleus Peternakan. 5(1):42-48.

Reksohadiprodjo, S. 1985. Produksi hijauan makanan ternak. BPFE. Yogyakarta.

Riwukore, J. R., \& F. Habaora. 2018. Sistem Produksi Sapi Potong. Deepublish Press. Yogyakarta.

Riwukore, J. R., \& F. Habaora. 2019a. Beef cattle productivity development strategy at Pasture Konetuef. International Journal of Current Research. 11(6):42444247.

Riwukore, J. R., \& F. Habaora. 2019b. Profile of existing population density and supporting capacity of beef cattle in Indonesia. International Journal of Recent Academic Research. 1(2):64-71.

Sahab, A., D. Darusman, \& Muladno. 2015. Pengolahan Taman Nasional Gunung Halimun Salak melalui pemberdayaan masyarakat berbasis pengembangan peternakan ruminansia. Risalah Kebijakan Pertanian dan Lingkungan. 2(2):86-96.

Saputra, J. I., Liman, \& Y. Widodo. 2016. Potential Analysis of Beef Cattle Livestock Development in Pesawaran Regency. Jurnal Ilmiah Peternakan Terpadu. 4(2):115-123.
Shiddieqy, M. I., Y. Widiawati, \& B. A. Ramadhan. 2017. Potency of availability and fullfillment of feed from cocoa plantation by products in South Sulawesi Province. Proceeding of National Seminar on Livestock and Veterinary Technology. Bogor (Indones): Indonesia Center for Animal Research and Development. p. 575584.

Suryani, N. N., I. G. Mahardika, S. Putra, \& N. Sujaya. 2015. Physical characteristics and digestibility of Bali cattle fed containing various forage. Indonesian J Anim Sci. 17(1):38-45.

Sesetyo. 1980. Padang penggembalaan: Suatu pengantar pada kuliah pengelolaan pasture dan padang rumput. Departemen Ilmu dan Makanan Ternak. Institut Pertanian Bogor. Bogor.

Tabun, A. C., N. N. Toelle, R. W. Sir, \& C. Leo Penu. 2016. Pemanfaatan jerami padi dan putak sebagai pakan induk sapi Bali di kelompok tani Kuinbes. Jurnal Pengabdian Masyarakat Peternakan. 1(1):32-39.

Voisin, A. M. 1995. Grass productivity. London: Crosby Lockwood \& Son Inc.

Wiryawan, K. G., A. Saefudin, A. M. Fuah, R. Priyanto, L. Khotijah, \& S. Suharti. 2017. Fermentation characteristics and nitrogen retention of Madura cattle fed complete rations containing soybean pod and byproducts. J Med Pet. 40(1):28-34.

Xu, J., Y. Hou, H. Yang, R. Shi, C. Wu, Y. Huo, \& G. Zhao. 2014. Effects of forage sources on rumen fermentation characteristics, performance, and microbial protein synthesis in midlactation cows. Asian Australias J. Anim.Sci. 27(5):667-673.

Yani, A., L. Zailzar, Sujono, \& Suyatno. 2011. Peningkatan kualitas dan ketersediaan pakan untuk mengatasi kesulitan di musim kemarau pada kelompok peternak sapi perah. Jurnal Dedikasi. 8:15-28.

Yuhendra. 2010. Analisis Interaksi Wilayah Komoditas Peternakan di Propinsi Riau. Jurnal Teroka. 10(2):19. 